\title{
The Subtlety of Subtales: Subaltern Voices of Sükșma Dharma in the Mahābhārata
}

\author{
Brian Black (iD
}

Accepted: 22 January 2022 / Published online: 23 February 2022

(C) The Author(s) 2022

\begin{abstract}
Many scholars have identified sūkșma dharma (subtle dharma) as a central theme of the Mahābhärata. However, beyond recognizing it as an understanding of dharma that is elusive and ambiguous, there has been relatively little investigation into the meaning and implications of sükșma dharma. As this article shows, even if the central episodes of the main story leave sükșma dharma undefined or unclear, the Mahābhārata's embedded narratives (upākhyānas) offer more explicit descriptions and demonstrations that can shed light on this otherwise elusive understanding of dharma. By focusing on three substories, the article argues that sükșma dharma is presented as a coherent and communicable teaching about how to act in morally ambiguous situations. This understanding of sūkșma dharma, as the article shows, is often associated with subaltern characters who demonstrate their knowledge through — what the article characterizes as — intuition and spontaneity in everyday situations.
\end{abstract}

Keywords Dharma · Mahābhārata · Sūkșma dharma · Subaltern · Upākhyāna · Substory

\section{Introduction}

Many scholars have identified the description of dharma as sükșma (subtle) as a central theme of the Mahābhārata. ${ }^{1}$ Indeed, A. K. Ramanujan has suggested that sükșma dharma is more central than dharma itself: "It is not dharma or right conduct that the Mahābhärata seems to teach, but the sūkșma or subtle nature of

\footnotetext{
1 See Ramanujan 1991a; Hara 1997; Hudson 2013; Adluri 2017; and Black 2021.
}

Brian Black

b.black@lancaster.ac.uk

Lancaster University, Lancaster, UK 
dharma -its infinite subtlety, its incalculable calculus of consequences, its endless delicacy....Dharma-sūkșmatā is one of the central themes that recur in an endless number of ways" (1991a: 435). Despite widely being regarded as a prominent teaching of the Mahäbhärata, if not its most distinctive one, there has been relatively little investigation into the meaning and implications of sükșma dharma, beyond recognizing it as an understanding that is elusive and ambiguous.

As indicated by Adam Bowles (2007: 101-3), the description of dharma as "subtle" has its background in the way that the Upanișads portray the highest knowledge. ${ }^{2}$ In the Upanișads teachers often present their teachings as beyond ordinary language and experience, characterizing core doctrines such as ätman and brahman as hidden or concealed, imperceptible or indescribable. ${ }^{3}$ As I will argue in this article, however, the description of dharma as sūkșma in the Mahäbhärata is not meant merely to characterize dharma as unfathomable or inexpressible, but rather is presented as a coherent and communicable teaching about how to act in morally ambiguous situations. This understanding of sükșma dharma, as I will show, is often associated with subaltern characters who demonstrate their knowledge throughwhat I shall characterize as-intuition and spontaneity in everyday situations.

Clearly, one of the reasons why many scholars of the Mahäbhärata have placed such importance on sükșma dharma is because it is invoked in some of the text's central deliberations about dharma - in particular, the discussion about Draupadī's polyandrous marriage and the debate about her status after the dicing match. As I have argued elsewhere, in these episodes and others in the central story, sūkșma dharma indicates an acknowledgment of dharma's range of meanings, including its ambiguities and tensions. ${ }^{4}$ Nevertheless, in these instances, characters such as Yudhișthira, Bhīṣma, and Draupadī make little attempt to explain what they mean by sükșma dharma or to offer specific examples. The ambiguity of these episodes has led Minoru Hara to see sūkșma dharma as pointing to the "weakness" or "unreliability" of dharma (1997: 516). Similarly, Emily T. Hudson (2013: 3-4) has taken its subtlety as conveying its ultimate ambiguity, which, as she argues, is part of the text's literary strategy of disorienting dharma. Although Hara and Hudson are correct that these central episodes remain unresolved, I think they are mistaken to interpret dharma's subtlety in terms of a weakness or disorientation. As I will show in this article, even if the central episodes leave sūkșma dharma undefined or unclear, the Mahābhārata's embedded narratives offer more explicit descriptions and demonstrations that can shed light on this otherwise elusive understanding.

Several scholars have noted that the Mahābhärata's embedded narratives act as mirrors or shadows of the main story. ${ }^{5}$ Vishwa Adluri has further suggested that a particularly important function of embedded narratives is to develop teachings about dharma in more detail. As he explains, a subtale and "other material that fit the category of "upākhyāna"" can be "understood as a narrative that either elaborates on

\footnotetext{
${ }^{2}$ For further discussion of Bowles' insights, see Hiltebeitel 2011: 99-101; and Adluri 2017: 5.

${ }^{3}$ For further discussion of rhetoric in the Upanișads, see Black 2011.

${ }^{4}$ See Black 2021: 60, 69-72, 117-19, 133-34, 178-81.

5 See, for example, Biardeau 1984, 1985; Hiltebeitel 2005; and Adluri and Bagchee 2016. See also Black 2021: 12-17, 186-88.
} 
some aspect of the main narrative or clarifies a specific dharma point" (Adluri 2016: 1-2). Building on this observation, this article will focus on three of only four occasions ${ }^{6}$ in the Mahābhärata where embedded narratives are used to explain or demonstrate sūkșma dharma: (1) Krṣṇa's stories of Balāka (a hunter) and Kauśika (a Brāhmaṇa ascetic); (2) Mārkaṇḍeya's narration of the Pativratā Upākhyāna, which includes stories of both a Devoted Wife (Pativratā) and a Hunter (Vyādha); and (3) Bhīṣma's account of Tulādhāra (a trader) and Jājali (a Brāhmaṇa ascetic). ${ }^{7}$ In addition to each of these narratives being framed as a demonstration of sūkșma dharma by the narrator, both Mārkaṇ̣eya's and Bhīṣma's accounts include characters within the story who further elaborate on sükșma dharma.

As we will see, not only are these embedded narratives framed in similar ways, but they also share a number of other features in common. In bringing attention to these shared features, I think we can usefully describe the embedded narratives told by Kṛ̣na, Mārkaṇdeya, and Bhīṣma as a "story cluster." Naomi Appleton and Chris Clark (forthcoming), building on the work of Ramanujan, discuss the notion of a "story cluster" in an attempt to move away from seeking chronology and influence between stories, while nevertheless recognizing the value of identifying a "pool of signifiers" that a group of stories have in common. Ramanujan describes "a pool of signifiers" in terms of "a shared core of names, characters, incidents, and motifs" (1991b: 46, 45). Some of the signifiers I will identify include resonances with the Upanișads, an emphasis on nonviolence (ahimsā), and the contrast between a Brāhmaṇa and non-Brāhmaṇa character. ${ }^{8}$ In this article, however, my point is not merely to recognize shared signifiers between these stories, but, more significantly, to show that when we read these stories together as a cluster we can gain new insights into the meaning and implications of sükșma dharma.

One of the signifiers that these embedded narratives share in common, as anticipated by Bowles, is their inclusion of Upanișadic tropes. ${ }^{9}$ As we will see, not only do these stories characterize knowledge as esoteric and elusive, but they also include Upanișadic imagery, such as comparing the self to a chariot (Katha Upanișad 3.3-9), presenting a soteriology of two paths (Bṛadāranyaka Upaniṣad

\footnotetext{
${ }^{6}$ The only other example of a subtale framed as a teaching about sükșma dharma appears in the Anuśāsana Parvan (13.10), when Bhīṣma tells Yudhișțira the story of the Śūdra and the Ṛ̣i. I do not include it here because it is not part of the same "story cluster" (see below).

${ }^{7}$ Of these embedded stories, only one is specifically called an upākhyāna. Nevertheless, they all fit the description of elaborating on dharma.

${ }^{8}$ Although the story of the Śūdra and the R̦și shares some similarities with the ones I discuss in this article (that is, the contrast between a Brāhmaṇa and non-Brāhmaṇa character), I do not include it here because it is not part of the same "story cluster." By this I mean that it does not contain the other "signifiers" that the other stories share, such as resonances with the Upanișads or an emphasis on nonviolence. Nor does it present sūkșma dharma as emerging from performing responsibilities towards others. Despite not sharing these similarities, however, the story of the Südra and the R̦̣i has some interesting implications for our understanding of sükșma dharma, some of which are in tension with the understanding of sükșma dharma as developed in the stories I am examining here. I hope to explore these tensions in a subsequent publication.

${ }^{9}$ For literary connections between the Upaniṣads and the Mahäbhärata, see Black 2018, 2021: 2-3; and Hegarty 2019.
} 
6.2.15-16; Chāndogya Upanișad 5.10), and equating the difficulty of knowing dharma with traversing the fine edge of a razor (Kața Upanișad 1.3.14).

Another shared signifier among these embedded narratives is the strong association between sükșma dharma and ahimsāa. As pointed out by Ian Proudfoot, ahims $\bar{a}$ has a variety of meanings, ranging from abstention from killing to a more general compassion for all living beings (1987: 2-3). Although the full range of these meanings appears across our three embedded narratives, the primary understanding of ahims $\bar{a}$ that all our stories have in common is an emphasis on not killing. Not only does each narrative explicitly warn against taking life, but collectively they expose the unintended violence of the lifestyle of renunciates. In both Kṛ̣ṇa's and Mārkaṇdeya's stories, in particular, renunciation is shown to lead to violence, however inadvertently. In this way, both Kṛ̣ṇa and Mārkaṇdeya use embedded stories about sūkșma dharma to explore the contradictions of renunciate life, showing that the pursuit of one's own spiritual goals can lead to the death, as well as injury and neglect, of others. ${ }^{10}$ Meanwhile, the teachings of the Pativratā, the Vyādha, and Tulādhāra equate ahimsāa with sūkșma dharma, while demonstrating that householders are better able to achieve this nonviolent ideal than renunciates.

Yet another shared feature among these embedded narratives is the motif of reversing the hierarchy between Brāhmaṇas and non-Brāhmaṇas. ${ }^{11}$ In each case, as we will see, sükșma dharma is not associated with Brāhmaṇas, but is illustrated through the actions and/or words of characters with a low or marginal social status, including a housewife, a hunter, and a trader. As I will argue, these characters portray sūkșma dharma both as inverting or violating traditional notions of dharma and as offering an understanding of dharma that is universally accessible, regardless of gender or caste.

Finally, I will argue that, taken together, these embedded narratives portray sükșma dharma as an understanding of dharma that is cultivated as an ongoing practice - a way or a path - that can lead to an intuitive grasp of how to act in morally ambiguous circumstances. In contrast to apad-dharma, which is a type of dharma that inverts normal codes of behavior, sūkșma dharma is way of understanding dharma that emphasizes its spontaneity and universal accessibility. As we will see, each embedded narrative-but particularly the teachings of the Pativratā, the Vyādha, and Tulādhāra-characterizes sūkṣma dharma as developed through the reflective performance of daily responsibilities towards others. In this way, sūkșma dharma is not a knowledge that can be calculated or discerned, but rather a disposition that is developed through continuous ethical behavior.

\footnotetext{
${ }^{10}$ Beyond criticizing Brāhmaṇa ascetics, this critique may well have been aimed at renunciate traditions such as Buddhism and Jainism.

${ }^{11}$ For a discussion of this trope in the Upanișads, see Black 2007a: 101-31.
} 


\section{Kauśika and Balāka (Mahābhārata 8.49)}

Krṣna is one of the Mahābhārata's central authorities on dharma. As Bimal Krishna Matilal suggests, Krṣna embodies "the ever-elusive character, the unresolved ambiguity of the concept of dharma" (1991: 404). However, only once does Kṛ̣na explicitly describe dharma as subtle. On this occasion, in the Karna Parvan, he is trying to convince Arjuna not to take revenge on his brother Yudhișthira. This discussion is part of an extended exchange between Kṛ̣na, Arjuna, and Yudhișthira, during which Yudhișthira criticizes Arjuna for returning from the battlefield and not staying to fight alongside Bhīmasena, when Karṇa had not yet been killed. Overcome by anger, Yudhișthira insults Arjuna and subsequently tells him to give up his Gāndịiva bow. At this point, Arjuna discloses a secret vow he has taken to kill anyone who asks him to give up his bow. Declaring that he will uphold his vow, he asks Kṛ̣na what he should do.

In response, Krṣna accuses Arjuna of not understanding the nuances of dharma, explaining that "it isn't at all easy to know what should or shouldn't be done" (8.49.19). ${ }^{12}$ Krṣna argues that dharma can be understood through śruti, but that Arjuna does not have the proper knowledge of tradition. As a consequence, Arjuna does not understand dharma and does not know when and when not to kill people. Then Krṣna asks Arjuna how he could attack his older brother without considering "the subtle (sūkșma) and unfathomable (duranvaya) way (gati) of dharma" (8.49.24). Kṛṣna offers a fuller understanding of this subtle and unfathomable way by revealing to Arjuna the "secret teaching of dharma" (dharma-rahasya). He begins this teaching by declaring that the one who speaks truth is "virtuous" and that "there is nothing higher than truth" (8.49.27). The difficulty, as Kṛ̣na explains, is that the "truth is certainly difficult in practice.... Falsehood is truth and truth is falsehood" (8.49.28-29). To illustrate this point, Kṛ̣na recounts two short parables, one of Balāka the hunter (vyādha) and the other of the Brāhmaṇa Kauśika.

According to Kṛ̣na, Balāka is a reluctant hunter, who does not take pleasure from killing, but does so to support his family, including his blind parents. Kṛ̣ṇa describes Balāka as following his own dharma (sva-dharma), always speaking the truth, and never spiteful (8.49.35). One day Balāka kills a wild creature who turns out to be an ascetic in disguise, intent on killing all living beings. Although Balāka is unaware of the creature's intentions, he goes straight to heaven after slaying it. Matilal interprets this fortuitous and rather surprising outcome in terms of "moral luck." As he explains: "The goodness of a good human life is not always dependent on the things that the moral agent can control.... Balāka was a good person in his own modest way, but external contingencies made his moral reward far greater than what he had dreamt of" (2002: 29). Indeed, Kṛṣna concludes from this story that dharma is "very difficult to understand" (sudurvida) (8.49.40).

Kṛ̣na then tells the story of Kauśika, a Brāhmaṇa who had taken a vow always to tell the truth, but who remained unlearned in śruti. On one occasion, Kauśika sees a group of people running away from some bandits. Because of his vow always to tell the truth, when asked by the bandits, he tells them which way the people went,

\footnotetext{
${ }^{12}$ Translations from the Karna Parvan loosely follow Bowles (Mahābhārata2008).
} 
which leads to their deaths. In this case Kauśika, who might seem to be virtuousboth because he has kept his vow and because he always tells the truth-ends up falling into a terrible hell. Kṛ̣na explains this outcome by once again invoking the description of dharma as sükșma, saying that Kauśika did not understand its subtle way (8.49.46).

Here we see that Krṣna introduces these two stories and concludes them by referring to the "subtle way of dharma." In other words, Kṛnna offers the stories of Balāka and Kauśika as examples of sūkșma dharma. We might wonder, then, how exactly these stories demonstrate dharma's subtle way. As we have seen, Kṛ̣na describes dharma as sükșma and difficult to understand (sudurvida) and portrays this subtle understanding as an esoteric teaching (dharma-rahasya). These descriptions of dharma have clear resonances with the rhetoric of subtlety that we often find in the Upanișads.

Krṣna also links the subtle way of dharma with ideas about nonviolence (ahimssa), particularly understood in terms of not killing. Indeed, at one point, he explicitly says that "one should never kill in any way at all" (8.49.20). In the Balāka story Krṣna brings attention to the fact that despite being a hunter, Balāka only kills to provide for his family. In the Kauśika story Kṛṣna characterizes the deaths of innocent people in the forest as evidence that Kauśika's actions led to an evil outcome. Meanwhile, Kṛnna tells these stories in the context of convincing Arjuna not to kill his brother.

Kṛnna also uses these stories to characterize sūkșma dharma as contradicting normal or expected understandings of dharma. Balāka goes straight to heaven, even though he impulsively kills another living being, whereas Kauśika goes to hell even though he upholds his vow always to tell the truth. Both cases illustrate that the dharmic quality of an action cannot be judged in isolation, that whether a certain kind of action upholds dharma depends on the circumstances. For Balāka, an otherwise immoral act takes him to heaven; for Kauśika, an otherwise virtuous act sends him to hell. This teaching is particularly relevant to Arjuna's circumstances, because Kṛṇa is trying to persuade him not to carry out a vow that would make him kill his own brother. In other words, Kṛnna invokes the subtle way of dharma to make the point that sometimes breaking a vow can be the right thing to do.

Despite the fact that in many ways he embodies dharma's subtlety, it is important to see how Kṛna's message here is in tension with his views on dharma in the Bhagavad Gìtā. Whereas in the Bhagavad Gìtā Kṛ̣na characterizes dharma primarily in terms of kșatriya-dharma and instructs Arjuna to adhere to it strictly, on this occasion he teaches a more complex understanding according to which he advocates behavior that would explicitly violate dharma based on caste duty. As Matilal has described it: "The same Kṛ̣na who advised Arjuna to fight the bloody war and kill his great grandfather for it was his duty as a ksatriya, prevented Arjuna on another occasion from killing his elder, Yudhisțhira, although that involved breaking the same code of conduct of a ksatriya: truth-keeping" (2002: 47). In this way, we might see Kṛnna's understanding of dharma as sūkșma in the Karna Parvan as offering a different model for ethical behavior than his teaching in the Bhagavad Gìtā. Kṛ̣na's portrayal of both karma-yoga and sūkșma dharma bring the ascetic ideal of self-control into the everyday practices of the householder. However, in the 
Bhagavad Gìtā Kṛṣna tends to present karma-yoga as adhering to varṇa-dharma, but here he characterizes sūkșma dharma as recognizing dharma's conflicting demands and as accepting that sometimes acting in opposition to established norms is the best way to uphold dharma.

\section{The Pativratā Upākhyāna (Mahābhārata 3.196-206)}

Another embedded narrative that is used to demonstrate the meaning of sükșma dharma is the Pativratā Upākhyāna. This extended subtale is part of a longer section of the Aranyaka Parvan where Mārkaṇ̣eya narrates a number of stories, dialogues, and teachings during the Pāṇuavas' period of exile in the forest. Mārkaṇdeya's main audience is Yudhișthira, who is accompanied by all four of his brothers, Krșna, and a number of Brāhmaṇas and seers. Crucially, as we will see, both Draupadī and Satyabhāmā (Kṛṣna's wife) are also listening to Mārkaṇdeya's narration. The Pativratā Upākhyāna contains two interlinked stories, one which recites the Brāhmaṇa Kauśika's encounter with a Devoted Wife (Pativratā), and the other which relates his encounter with a Hunter (Vyādha).

\section{The Pativratā (3.196-197)}

Mārkaṇdeya recounts the Pativratā Upākhyāna in response to Yudhișthira's request to hear about the greatness of women, sükșma dharma, and the difficulties of stridharma (3.196.2-8). The fact that Mārkandeya responds by reciting the story of the Pativratā indicates that he considers this account to be an illustration of dharma's subtlety, in the same way that Kṛ̣na recited the stories of Balāka and Kauśika to demonstrate the subtle way of dharma to Arjuna.

Mārkaṇdeya begins his account with an episode featuring the Brāhmaṇa Kauśika. We will return to the implications of this particular character's association with stories illustrating sūkșma dharma below. Unlike Kṛ̣na, who describes him as unlearned in śruti, Mārkaṇdeya portrays Kauśika more favorably, as a "distinguished Brāhmaṇa," "scholar of the Vedas," "great ascetic," and "dharmapracticing ascetic," who had studied all the Vedas, including the Upanișads (3.197.1-2). One day, while reciting the Vedas under a tree, a female egret (balākā) defecates on his head. ${ }^{13}$ When Kauśika stares at the egret angrily, she falls to the ground lifeless. Feeling compassion for the egret and tormented by what he has done, Kauśika says to himself: "I have done wrong because passion and hatred overcame me" (3.197.6). ${ }^{14}$ Kauśika then goes to a nearby village to beg for food.

At one of the houses, the Pativratā keeps him waiting at the door while she attends to her husband. In the meantime, Kauśika becomes angry and, when she returns, asks why she had made him wait. The Pativratā replies that she was looking after her husband: "My husband is my greatest deity (daivatam mahat), and he came home hungry and tired, and I saw to his wants" (3.197.20). In response, Kauśika

\footnotetext{
13 Here I am following Leslie's rendering of balāka (1998: 464, 475).

14 Translations of the Pativratā Upākhyāna loosely follow van Buitenen (Mahābhārata1975).
} 
accuses her of belittling Brāhmaṇas, reminding her of their destructive powers. She then apologizes, saying that she is aware of the powers of Brāhmanas, explaining that through her obedience to her husband, she knows that Kauśika has killed a female egret.

After revealing that she knows what Kauśika has done, she instructs him that a Brāhmana is someone who is "master of his senses, intent on dharma, devoted to Veda study, pure, and in control of desire and anger" (3.197.33). He considers all the world as himself and has love for all dharmas. Proclaiming that the constant (śā́sata) dharma is difficult to know (3.197.39), the Pativratā then describes dharma as subtle: "Many a time dharma has been seen as sūkṣma, great Brāhmaṇa, and you too are aware of dharma, devoted to study, and pious; yet sir, I do not think you know dharma really" (3.197.40). She then concludes her teaching by advising Kauśika to seek out a hunter (vyādha) living in Mithilā, who will instruct him further on dharma. She describes the hunter as "obedient to his father and mother, true-spoken," and "in command of his senses" (3.197. 41). Although the story of the Pativratā ends here, Mārkaṇdeya's narration continues as he recounts Kauśika's encounter with the Vyādha.

Before moving on to Kauśika's encounter with the Vyādha, let us reflect on how the story of the Pativratā characterizes the subtlety of dharma. As we have seen, it is Yudhișthira's initial question about sūkșma dharma that prompts Mārkaṇdeya to narrate the encounter between the Pativratā and Kauśika. Additionally, within the story itself, the Pativratā explicitly describes dharma as sūkṣma, while equating her own knowledge of dharma as emanating from her devotion to her husband.

Although the fact that the Pativratā is teaching a Brāhmana seems to highlight women's contributions to articulating dharma, her instruction could also be seen as reinforcing a patriarchal agenda that defines the role of women in terms of serving men. Indeed, Arti Dhand has made arguments along these lines. As Dhand points out, despite being portrayed favorably in this story, the Pativratā remains nameless (2018: 99), referred to by her role as "devoted wife" (pativratā)—a role that is often associated with the most restrictive and oppressive aspects of the dharma of women (strī-dharma). As such, Dhand interprets the Pativratā as exemplifying "a specific brand of karmayoga," which promotes doing one's duty "even where it meets with indifference, neglect, or abuse" (2018: 100). By strongly connecting the Pativratā with this "specific brand of karmayoga," Dhand argues that the Pativratā exemplifies the "female subaltern," who "defends and lauds her subordination as an incontrovertible virtue and chastises others who deviate from it. Its basic imperative of 'Don't think, just do' kills the agency of the female moral agent and consigns her entire intellect to the service of a worldview in which she has no independent worth" (2018: 101).

Similarly, in her analysis of this story, Maithili Thayanithy argues that the representation of "subaltern members of society as preceptors and exemplary followers of householder dharma (pravrtti dharma)...reinforces the Brāhmanical vision of a hierarchized society" (2018: 189). Furthermore, Thayanithy argues that the portrayal of "women as submissive, disciplined adherents" of the pativratā ideal "arises from the Brāhmanical desire to exert absolute control over them" (2018: 206). 
Although both Dhand and Thayanithy raise some crucial issues, I find their interpretations ultimately limiting. As I will suggest, there are ways of reading this episode that highlight the Pativratā's agency and the potentially empowering implications of her teaching. One of the limitations of their arguments, especially as articulated by Thayanithy, is that their starting point is reading the Mahäbhärata as expressing a narrowly conceived ideological agenda. Building on arguments made by James L. Fitzgerald (2006) and Johannes Bronkhorst (2011), Thayanithy states explicitly that her interpretation "is premised on the notion that the Mahäbhärata... was fashioned to forge a new brāhmaṇa-kṣatriya partnership in the political domain and to re-establish Brāhmanical dominance in the social sphere through the ideology of dharma" (2018: 190). Although it is not my intention in this article to propose a countertheory for the complex issue of the Mahābhärata's authorship, I think that the text's variety of material and diversity of views cast doubt on the theory that it represents a Brāhmanical desire to exert control. Clearly, there are many passages throughout the text that express a very conservative and hierarchical understanding of the social order. However, there are also countless examples where such understandings are questioned, challenged, or rejected. With this in mind, I find it more helpful to approach the Mahābhärata, following Tamar Chana Reich (1998: 22-32), as a heterogenous text that includes opposing points of view, sometimes in "contestatory" relationships. In other words, I think we get a deeper appreciation of the Pativratā's teaching in this story if we see the Mahābhārata as including a number of competing voices that do not always agree with each other.

Another reason why I consider Dhand's and Thayanithy's interpretation of the Pativratā's story to be limiting is because they offer a rather narrow way of understanding agency. Both seem to assume that agency can only be understood in terms of challenging the Brāhmanical social system. In seeking a broader understanding of agency, I have in mind the arguments of Saba Mahmood, who criticizes feminist theory for conceptualizing agency as "liberatory" and therefore limited to "the binary model of subordination and subversion" (2006: 42). In other words, agency should not be understood only in terms of challenging the social structure; rather, as Mahmood (2006: 36-37) points out, values that are associated with subordination, such as feminine passivity and submissiveness, can also be idioms through which women assert their presence in a previously male-defined sphere. With Mahmood's arguments in mind, I think it is reductive to read the story of the Pativratā only in terms of how it might reinforce a conservative Brāhmanical agenda. We should also be attentive to what this story might be saying about how the pativratā ideal can be invoked by women to assert themselves in the otherwise male-dominated domain of shaping understandings about dharma.

Indeed, when reading her story in the context of other embedded narratives that demonstrate sūkșma dharma, we might see the Pativratā, not as lacking agency, but as embodying an understanding of dharma in which she can rely on her own intuitions and judgments. As we have seen, her devotion to her husband and others is made possible through her virtuous conduct ( $s \bar{a} d h v \bar{a} c \bar{a} r \bar{a})$ and her command of her senses, as well as her good qualities, such as being pure (śuc $\vec{l})$ and clever (dakșa $)$ (3.197.14). In this way, her teaching does not characterize her devotion only in terms of submission, but also in terms of combining ascetic ideals of controlling her 
thoughts and actions with dharmic ideals of responsibility towards others. With this in mind, we might see the Pativratā's understanding of dharma's subtlety not as grounded exclusively in her service to others, but more broadly in her ability to control her passion and anger.

It is also notable that when the Pativratā describes dharma as sūkșma, she contrasts her own knowledge with Kauśika's lack of understanding. Within the story, the difference between the Pativratā and Kauśika is measured by how they control their emotions. While Kauśika is quick to anger, both when he inadvertently kills the egret and when he becomes impatient with her, the Pativratā is characterized as being in control of her thoughts and emotions. Indeed, in contrast to Kauśika, who loses control when he casts an angry glance, Pativratā describes dharma as constant (śáśvata) (3.197.39), perhaps indicating that her practice does not suffer from momentary lapses of concentration.

We should also note that she includes in her understanding of dharma the study of the Vedas, while invoking an Upanișadic ethic of regarding all living beings as having the same nature (3.197.34). This dimension of her teaching indicates that her understanding of dharma is not based completely on servitude, but also on learning traditional texts and teachings. Despite the well-known sāstric injunctions against women learning traditional texts and teachings, the Pativratā not only demonstrates a familiarity with Vedic sources, but also invokes them to support her own authority as a teacher of dharma.

Finally, when Kauśika reflects on sükșma dharma, he is persuaded by the Pativratā's teaching because of "her convincing mention of the egret, and her dharma-like (dharmya) and virtuous (śubha) discourse" (3.198.4). In other words, according to Kauśika's reflection, the Pativratā demonstrates her understanding of dharma's subtlety by revealing what she knows and by articulating her knowledge in a convincing way. In this way, the Pativratā is not depicted as merely a passive housewife who performs her duties without question, but rather as actively displaying her knowledge and communicating it to others.

It is also worth noting that the Pativrata is not the only female character to describe dharma as sūkșma in the Mahābhārata. As mentioned above, Draupadī invokes sūkșma dharma in her argument for her own freedom after the dicing match (2.60.31). As I have argued elsewhere, Draupadī refers to dharma's subtlety to help challenge the results of the dicing match and bring attention to her own ethical behavior (Black 2021: 117-34). The Pativratā's connection with Draupadī is particularly relevant because Draupadī, along with Satyabhāmā, is in the audience when Mārkaṇdeya narrates the Pativratā Upākhyāna. ${ }^{15}$ After this subtale, Draupadī and Satyabhāmā remain for one more of Mārkaṇḍeya's narrations, before going inside together to have a private conversation (3.222.1). It is at this point that Draupadī shares with Satyabhāmā her own understanding of the role of the pativratā: "My dharma rests on my husband, as, I think, it eternally does with women. He is the God, he is the path, nothing else" (3.222.35). Here, Draupadī's teaching might seem to support Dhand's and Thayanithy's understanding of the pativrata, as a role for women that is both restrictive and oppressive. However,

$\overline{15}$ For the importance of listening and eavesdropping, see Black 2007b. 
Draupadī also tells Satyabhāmā that her responsibilities as a patrivratā include managing the household and keeping track of the king's treasury. Moreover, she twice mentions her husband's obedience to her (3.222.37, 3.222.56). As Laurie L. Patton argues, Draupadī not only conveys "the classic pativratā devotion," but she also shows her "awareness of the basic power dynamics between men and women, as well as her sense of her own power and agency within a given situation" (2007: 100, 100-101). Like the Pativratā, Draupadī not only practices everyday acts of devotion, but also does so reflectively and is able to communicate her practice to others. We might infer that it is Draupadī's practice of pativratā that endows her with an understanding of dharma's subtlety, which she refers to in the assembly hall after the dicing match (2.60.31).

Returning to the Pativratā, we have noted that Dhand and Thayanithy raise important issues when interpreting her story as reinforcing a submissive and subservient understanding of a wife's devotion to her husband. Nevertheless, I have also suggested that when we see her story as an illustration of sūkșma dharma, we can recognize that the Pativratā's teaching is multifaceted and potentially empowering for women in navigating their own spiritual progress. Although the Pativratā's dharma requires devotion to her husband, her soteriological accomplishments do not depend on his actions. In this way, the Pativratā has considerable agency in shaping her own destiny. Taken together, the Pativratā's teaching to Kauśika characterizes sūkșma dharma as the highest understanding of dharma: an understanding that is based on conduct rather than birth and one that, despite its difficulty, can potentially be achieved by anyone, regardless of gender.

\section{Kauśika and the Vyādha (3.198-206)}

Mārkaṇdeya begins his account of Kauśika's encounter with the Vyādha by returning to the topic of subtle dharma. According to Mārkandeya, before seeking out the Vyādha, Kauśika pondered "on the subtle way of dharma" (dharmasya sükșmām gatim; 3.198.2). It is at this point that he reflects on the Pativratā's convincing words and virtuous discourse (3.198.4). When Kauśika finally reaches Mithilā, some Brāhmaṇas help him find the Vyādha. Like the Pativratā, the Vyādha is not given a personal name, but is referred to as a vyādha, which typically means "hunter." In this story, however, the Vyādha works as a butcher in a slaughterhouse. The Vyādha greets Kauśika and reveals that he knows that the Pativratā has told him to come to Mithilā. They then go to the Vyādha's house, as he thinks that the slaughterhouse is an inappropriate place for a Brāhmaṇa. After accepting food and water back at the Vyādha's house, Kauśika addresses him, saying that his occupation does not suit him. The Vyādha responds, explaining that it is his family occupation, passed down from his father and grandfather. He then says that different people have different duties.

At this point, the Vyādha offers a long discourse that includes a number of themes that appear repeatedly in embedded narratives about sūkșma dharma. The Vyādha defines dharma in terms of conduct rather than birth $(3.198 .70,3.203 .11)$ and speaks of the importance of acting selflessly (3.203.43). He also offers a number of teachings with resonances with the Upanișads, such as an ethical understanding 
of karma (3.199.1-3, 3.199.14-15); the immortality of the self (3.200.25-26); and understanding the self (ätman) as the highest knowledge (3.203.46). Moreover, he recites a verse that has strong connections with the chariot metaphor as articulated in the Kața Upanișad (3.202.21-22).

The Vyādha also stresses the importance of nonviolence (3.198.80, 3.199.19-26, 3.203.45), at one point calling it the highest dharma (3.198.69). He also extends his emphasis on ahimsa $\bar{a}$ beyond the abstention from killing to urging compassion for all creatures $(3.198 .40,3.198 .81,3.198 .91)$ and calling nonharm (ärŕśamsya) the highest dharma (3.204.41). However, unlike Kṛṣna's unreserved criticism of taking life in the Karna Parvan (or Tulādhāra's teaching below), the Vyādha tempers his teaching with a defense of his position as a butcher in a slaughterhouse. As he explains, one can eat meat without incurring guilt if one makes the correct offerings to the deities and ancestors (3.199.11). He also argues that even those ascetics dedicated to nonviolence are inadvertently violent towards others, even if their practices decrease violence (3.199.28-29).

During his instruction, the Vyādha twice describes dharma as sūkșma. Both instances appear early on in his teaching, when making the point that dharma does not always follow expected patterns: "Much in this world can be viewed as upside down, good Brāhmaṇa, adhering to dharma or adharma" (3.199.33). Here, the Vyādha concludes: "the way of dharma is subtle indeed" (sükșmā gatir hi dharmasya; 3.200.2). Perhaps foreshadowing Kṛṣna's teaching to Arjuna in the Karna Parvan, the Vyādha further explains to Kauśika that sometimes a lie is the truth and the truth a lie: "One may voice a lie when about to expire or when about to marry: then the lie becomes truth and the truth a lie. It is generally held that truth is that word that is entirely beneficial, and that the opposite creates adharma" (3.200.3-4). The Vyādha then reiterates: "notice the subtle nature of dharma" (dharmasya sūkșmatām; 3.200.4). Here, like Kṛ̣na, the Vyādha associates dharma's subtlety with the inversion of dharmic norms, such as telling a lie or breaking a vow.

Towards the end of his instruction, the Vyādha takes Kauśika to meet his parents at their house, where he shows that he is a devoted son who treats them like gods. Similar to how the Pativratā describes her loyalty to her husband, the Vyādha calls his parents his "highest divinity" (daivatam param) (3.204.17). Continuing on the theme of inverting dharma, he tells Kauśika: "I do things for them even if it means violating dharma, as long as they are pleased" (3.204.24). After leaving his parents' house, the Vyādha accuses Kauśika of not paying his own parents proper respect when he became a renunciate, urging him to return to them at once to comfort them. As he explains: "You are austere, great-spirited, and delighting in dharma; all this may prove meaningless, unless you placate your parents" (3.205.9).

Kauśika then praises the Vyādha for his teaching, but says he is unconvinced that such a wise discourse could have been transmitted by someone who is not a Brāhmana: "The constant (śäśvata) dharma is obscure to one who has been born a Śūdra. I do not think you are a Śūdra" (3.205.19). The Vyādha replies that he was a Brāhmana in his past life, explaining that once while hunting he shot a hermit by mistake. As a consequence, the sage cursed him to be born a hunter. Out of noncruelty (annrśamisya), the sage modified his curse, allowing the Vyādha to retain his memory, be a knower of dharma, and pay obedience to his father and mother 
(3.206.5). Kauśika then proclaims that a Sūdra can attain the status of Brāhmana through conduct (3.206.12). According to Mārkaṇdeya, Kauśika "was thereafter completely obedient to his father and mother, to his elders, according to the rules, for he was now firmly resolved" (3.206.30). Mārkandeya concludes the story by returning to Yudhișthira's initial question, saying: "I have fully related to you...the dharma about which you asked me" (3.206.31).

As we can see, there are a number of shared signifiers between Kṛ̣na's tales of Balāka and Kauśika and this one offered by Mārkandeya. Both recount the deeds of a Brāhmaṇa named Kauśika, and both include a character referred to as Balāka/ balāka (one a hunter and one an egret) and a hunter (vyādha) who mistakenly kills the wrong creature. Both Kṛ̣ṇa and Mārkaṇḍeya portray Kauśika as a Brāhmaṇa who lacks an understanding of dharma and compare him unfavorably to a hunter known for his loyalty to his parents. ${ }^{16}$ In both accounts Kausika is depicted as a truth-teller and a vow-taker ${ }^{17}$ who practices severe austerities, but who does not fully understand dharma, and whose lack of understanding leads to the death of innocent living beings. In Kṛ̣ṇa's account, Kauśika's ignorance has particularly severe consequences, as his refusal to break his vow leads directly to the death of an unspecified number of humans. For this he suffers a terrible hell. In Mārkaṇdeya's account, Kauśika's lack of constant attention to dharma leads to an instant where he loses self-control, thus killing an egret merely by staring angrily. Mārkaṇụeya's account is generally more sympathetic to Kausika, despite the fact that his lack of knowledge also leads to an innocent death. Rather than falling to a terrible hell, Kauśika immediately embarks on a path towards redemption by seeking alms. His impatience with the Pativratā indicates that he still has much to learn when he arrives at her door, but nevertheless he is willing to listen to her explanation and then her teaching, declaring afterwards to himself that she understands the subtle way of dharma. He then goes off to seek the instruction of the Vyādha. Although he has his reservations at first, he appears to receive the Vyādha's teaching with an open mind and by the end indicates that he has been transformed by this teaching. Rather than falling to a terrible hell, as he does in Kṛ̣na's story, Kauśika tells the Vyādha: "I was falling to hell and you saved me" (3.205.16).

Given the comparable depictions of Kauśika, it is interesting to note the similarities between the two vyādha characters. Although their occupations are different-one is a hunter, while the other is a butcher-both are known for their loyalty to their parents. This is not expanded upon in Kṛṇa's more concise account, but it is still mentioned, with the detail that Balāka's parents are blind offering additional emphasis. In Mārkaṇdeya's account, the Vyādha's loyalty to his parents is more explicitly emphasized; indeed, it is one of the central messages of his teaching. Not only does he tell Kauśika about his loyalty to his parents, but he takes

\footnotetext{
${ }^{16}$ It is not clear why Kausika is portrayed in this way, but Thayanithy notes that the meaning of his name, "which, among other things, is sacred grass" (2018: 200) could indicate that he is turning his back on the sacrificial tradition. It is also worth mentioning that his name appears in two genealogies in the Bṛhadāranyaka Upaniṣad $(2.6 .1,4.6 .1)$ and that Kauśika is the gotra name of Viśvāmitra, who is known for his ambiguous caste status.

17 Although Kauśika's vows are far more central in Krṣṇa’s story, he is nevertheless characterized as strict in his vows in Mārkaṇ̣eya's narration as well (3.205.4).
} 
Kauśika to their house to meet them. While in their company, he tells the Brāhmana that he reveres them as his highest divinity and refers to his loyalty to his parents as "the constant dharma" (3.204.26). At the end of his teaching, he indicates that Kauśika's lack of understanding of dharma stems from him not being devoted to his parents. Finally, he instructs Kauśika to go to them immediately (3.205.5-10).

The theme of family obligation is amplified when we see Mārkaṇdeya's account of the Vyādha's teaching in relation to his previous account of the Pativratā. Whereas the Pativratā derives her superior understanding of dharma from her devotion to her husband, the Vyādha derives his from his loyalty to his parents. Considering the Pativratā and the Vyādha together, we see that an important part of sükșma dharma is acting selflessly towards others, especially one's family members. With this mind, we might return to Kṛ̣ṇa's story of Balāka and question whether his ascendance to heaven was really down to "moral luck," as Matilal has suggested. Rather, we might infer that his ability to enact dharma spontaneously was cultivated through his loyalty to his parents, in the same way that the Pativratā and the Vyādha develop their intuitive understanding of sükșma dharma through their daily practices of loyalty and devotion to their family members.

Finally, both Krṣna and Mārkaṇdeya use their stories to set up a contrast between a Brāhmana's understanding of dharma and the understanding of someone from a lower or marginal social status. Dhand and Thayanithy, similar to the points they raise in relation to the Pativratā, have questioned the degree to which the Vyādha can legitimately represent agency for subaltern voices. Noting that at the end of Mārkaṇdeya's account the Vyādha reveals that he had been a Brāhmaṇa in a previous life, Dhand sees the story as restricting his agency as a Sūdra: "What is notable here is that in this case, the subaltern cannot claim even his wisdom and virtue as his own" (2018: 102). According to Dhand, the Vyādha, "virtuous as he is, represents the archetypal docile native-claiming his servitude as his own fault, evolving an elaborate theodicy of injustice, humbly effacing himself before the elite; surrendering all positive values as the bequest of the empowered" (2018: 103).

Again, Dhand raises some important issues. However, I think some of these concerns are mitigated when we keep in mind the similarities that this story has with others about dharma's subtlety. As I am suggesting throughout this article, these stories, taken together, demonstrate that sükșma dharma is not exemplified through extraordinary acts that only the most advanced ascetics can perform, but rather through the everyday activities through which male and female householders can express devotion and service to others. Although the Vyādha reveals that he was a Brāhmaṇa in a previous life, his teachings also inspire Kauśika to proclaim: "Any Sūdra who is always intent upon self-control, truthfulness, and dharma, I judge him a Brāhmaṇa; for one becomes a Brāhmaṇa through one's conduct" (3.206.12). Kauśika's words here could be seen as reinscribing the superiority of Brāhmaṇas, but they can equally be seen as reframing the definition of Brāhmaṇa in terms of conduct rather than birth. In other words, rather than taking agency away from the Vyādha, this story indicates that anyone, regardless of caste or gender, can achieve the highest knowledge. 


\section{Jājali and Tulādhāra (Mahābhārata 12.252-256)}

Another story that is offered as a demonstration of dharma's subtlety is the encounter between the Vaiśya Tulādhāra and the Brāhmaṇa ascetic Jājali. This story, which appears in the Śanti Parvan, is told by Bhīṣma in response to Yudhișthira's extended question about the nature of dharma. As Yudhișthira reflects, Bhīṣma has already indicated the "subtle mark of dharma" (sükșmam dharmalakșanam; 12.252.1), but Yudhișthira still wants to know whether it is "possible to know dharma completely" (12.252.3). ${ }^{18}$

As Yudhișthira explains, his confusion arises from the fact that there are different dharmas for different people (12.252.4) and that sometimes adharma comes in the guise of dharma. He points out that dharma cannot be known by studying texts, since it varies according to circumstance and different eras and because the sacred texts contradict one another (12.252.9-10). Using Upanișadic imagery, Yudhișțira describes dharma as "finer than the edge of a razor"19 and "more massive than a mountain" (12.252.11-12). He then laments that the constant (śāśvata) dharma has disappeared (12.254.14), before returning to the multiplicity of dharmas, saying that there is no mode of behavior that is universally beneficial (12.252.20). He concludes his question by indicating that dharma needs a firmer foundation than the "custom of earlier times" (12.252.20).

Here, Yudhișthira portrays dharma as sükșma because of its apparent contradictory nature. Yudhișthira, who, more than most other characters in the Mahābhärata, yearns for a more consistent and universal understanding, seems perplexed that dharma can be so ambiguous and unpredictable. Yudhișthira's description of the "subtle mark of dharma" has some overlapping features with what Krṣna calls the "subtle way of dharma," as well as with his own understanding of sūkșma dharma in the Aranyaka Parvan. Like Kṛ̣na, Yudhișțira mentions the inversion of norms as a characteristic feature of dharma's subtlety. Also, like Krṣna, Yudhișthira characterizes sūkṣma dharma as difficult to understand.

In response to Yudhișthira's request for further explanation about "the subtle mark of dharma," Bhịṣma recites the ancient story of Tulādhāra and Jājali. According to Bhīṣma, Jājali lives in the forest for many years, practicing extreme asceticism: he wears only rags and goes without eating or speaking for long periods of time. One day, he uses his yogic powers to travel "with the speed of thought throughout the world" (12.253.4). Full of pride, Jājali wonders to himself whether anyone else in the world can travel around the world in this way (12.253.6). He is overheard by some demons, who advise him that he should not speak in this way, that even the renowned Tulādhāra, a trader in Vārānasīin, would not be worthy of speaking like this. After hearing this, Jājali sets off in search of Tulādhāra.

At this point of Bhīṣma's narration, Yudhișthira asks to hear in more detail about Jājali's "meritorious works" (12.253.12). In response, Bhīṣma recounts that Jājali remained motionless for years, while a pair of sparrows set up a nest in his matted hair. The birds then had chicks that grew up and learned how to fly during the time

\footnotetext{
${ }^{18}$ Translations of the Tulādhāra episode loosely follow Proudfoot (1987).

${ }^{19}$ See the Kața Upanișad (1.3.14).
} 
they lived in Jājali's hair. All the while Jājali remains motionless, with Bhīṣma describing him as "fixed upon his vow" (samśita-vratah) (253.24) and "firm in his vow" (yata-vratah) (253.28). Finally, when the young birds leave the nest for the last time, Jājali begins to think highly of himself, declaring that he has "achieved dharma" (253.41).

Upon hearing his boast, an invisible voice from the sky warns him that "in dharma," he is not the equal of Tulādhāra (12.253.42). According to the voice, even the wise Tulādhāra, a merchant who lives in Vārānasīi, "would not be worthy to say such words" (12.253.43). Hearing this, Jājali becomes angry and decides he must go and see this man. ${ }^{20}$ Bhīṣma's narration continues with Jājali arriving in Vārāṇas̄̄ and Tulādhāra receiving him as an honored guest. Tulādhāra then reveals that he knows all about Jājali: his austerities, the birds that lived in his hair, his boastful claim to have won the greatest merit of all living creatures, and the voice from the sky that spoke to him. When Tulādhāra asks him what he can do for him, Jājali replies by asking how he has become knowledgable when his daily routine is buying and selling bark, leaves, herbs, fruit, and roots (12.254.2).

Tulādhāra responds with a long instruction. But before recounting it, Bhīṣma describes Tulādhāra as "aware of the essential meaning of dharma" and as speaking of "the subtleties of dharma" (dharma-sūkșmāni) (12.254.4). By describing Tulādhāra and his instruction in this way, Bhīṣma not only portrays him as knowledgeable, but also indicates that his teaching itself is a demonstration of "the subtleties of dharma."

Throughout his instruction, Tulādhāra addresses a number of themes that we have seen in the other episodes. Indeed, Tulādhāra begins by characterizing his teaching as secret, in the same way that Krṣna began his teaching of subtle dharma: "I know the ancient (sanātanam) and secret (sarahasyam) dharma (dharmam)" (12.254.5). Additionally, Tulādhāra's teaching emphasizes nonviolence. Not only does he use the term ahimsā several times (12.254.20, 12.254.29, 12.255.24, 12.256.6), but on one occasion he equates ahimsā with the highest dharma (12.254.29). Moreover, like the Vyādha, he also extends his understanding of ahimsā beyond not killing to nonharm and compassion for others. He associates dharma with "compassion for the welfare of all creatures" (12.254.5), he announces that he lives by "that conduct which is the highest dharma, without harm to creatures, or failing that with a minimum of harm" (12.254.6), and he equates knowing dharma with always being a friend of all creatures and always acting for the good of all creatures (12.254.9).

Another theme that Tulādhāra's instruction shares in common with the teachings from our other embedded narratives is the equation of dharma with selflessness and acting dispassionately. Tulādhāra explains: "I am never in accord or disaccord; I neither hate nor love; I am neutral with regard to all creation" (12.254.11). He explains that he is "devoid of the desire for the enjoyments of wealth and pleasure" (254.15) and that he follows "the hereditary practice" of his "right-acting, noble-

\footnotetext{
${ }^{20}$ Proudfoot argues that the two different accounts of Jājali's ascetic exploits are the result of bringing together two different versions of this story. Although this is possible, here I am taking a synchronic reading, as by doing so we can explore the most resonances with other stories demonstrating sūkșma dharma.
} 
minded, and gentle ancestors" (12.254.20). Here, like the Pativratā, Tulādhāra emphasizes control over emotions, and, like the Vyādhā, he emphasizes that his vocation is his hereditary duty. Then, echoing Yudhșthira's words in his initial question to Bhīṣma, Tulādhāra describes the constant (śāśvata) dharma as lost (12.254.21).

After opening his teaching with these familiar topics, Tulādhāra then returns to the theme of the subtlety of dharma: "O Jājali, there is indeed nothing without cause, dharma is subtle (dharmahsūkșmo)...because of its subtlety (sūkșmatvān), it cannot be fully understood" (12.254.35-36). According to Proudfoot: "Tulādhāra's response moves in two ways: it deals with the conceptual problem presented by human inability to comprehend dharma; and it sets out a practicable mode of conduct which transcends the limitations of imperfect understanding" (1987: 102). Here, I would agree with Proudfoot that Tulādhāra presents sūkșma dharma as an embodied practice that acknowledges the limitations of a purely conceptual understanding of dharma.

However, I think Proudfoot goes too far when he describes Tulādhāra's equanimity as "an uncaring, uninvolved, emotionally-dead passivity" (1987: 113). Rather, I would argue that Tulādhāra equates his understanding of dharma with a way of acting that resonates with the personal loyalty of the Pativratā towards her husband and of the Vyādha towards his parents. Although this mode of conduct resembles karma-yoga in the sense that it is rooted in actively performing duties and obligations towards others, I think Proudfoot takes a rather extreme position when describing Tulādhāra as having "total unconcern with what his behaviour might lead to" (1987: 102). In contrast, I think Tulādhāra's main emphasis is that dharma is not upheld by following a formula. In other words, I would suggest that Tulādhāra presents an understanding of dharma's subtlety as not only grounded in traditional practices of loyalty and responsibility, but also as performed in response to evervarying concrete situations. In this sense, as we will see, Tulādhāra's understanding of sūkṣma dharma is not passive, but both intuitive and spontaneous.

After describing dharma as sūkșma, Tulādhāra returns to the topic of nonviolence, discussing the mistreatment of animals (12.254.37-49). He concludes this section by characterizing his subtle teaching as an inversion of traditional teachings. As he puts it: to follow dharma, one should "not follow the ways of the world" (12.254.50). Again, we see dharma's subtlety characterized in terms of reversing established norms and acting in ways that might initially seem to be in contravention of dharma.

Jäjali replies, saying that the dharma he expounds will close the door to heaven and stop the livelihood of all creatures (12.255.1), accusing Tulādhāra of being a heretic (12.255.3) because the world would stop any productive activity if his teachings were followed. Tulādhāra responds with a discourse on reinterpreting Vedic ritual to avoid harm to animals. According to Tulādhāra, the gods can be pleased without animals being killed. As Proudfoot explains: "Tulādhāra argues that Jājali is mistaken in believing that sacrifice needs to involve killing, and that it is possible to maintain the circulation of life in various ways without sacrificial killing" (1987: 127). 
Tulādhāra then returns to the topic of dharma, saying that those who "delight in dharma" and "rejoice in dharma" achieve the state of brahman in this world (12.255.21-23). At this point, Tulādāra alludes to the Upanișadic two paths of the dead (12.255.29). After explaining his teaching further, Tulādhāra then points to the sky and says that among the birds flying above are the very ones that had hatched in the nest in Jājali's hair (12.256.2). He asks Jājali to call them and when they come, they affirm that Tulādhāra has a superior understanding of dharma (12.256.16). Bhīṣma concludes the story, saying that Tulādhāra and Jājali both "ascended to heaven...having reached their respective places earned by their respective acts" (12.256.16).

At the end of this episode, Bhișma returns to the subtlety of dharma by concluding his story with a song (gìt $\bar{a})$ attributed to King Vicakhnu (12.257.1-11), who had initially recited it "out of compassion for living creatures." Observing the cruelty that a bull endures during a Vedic ritual, the king compassionately blesses all cattle. During his blessing, Vicakhnu refers to dharma as sūkșma: "Therefore, the subtle dharma (dharmah sükșmo) [which] should be performed is considered by the discerning one to be indeed nonviolence (ahimsā), the best of all dharmas" (12.257.6). Here, ahims ā, understood in terms of not killing, is declared the highest dharma and equated with sūkṣma dharma. Meanwhile, by concluding the Tulādhāra and Jājali story with these words attributed to King Vicakhnu, Bhīṣma frames this entire episode as a demonstration of the subtle nature of dharma.

As we can see, there are a number of overlapping themes between Bhīṣma's story of Tulādhāra and Jājali and the embedded narratives we have examined above. In particular, as several scholars have pointed out, there are a number of similarities between the encounter between Tulādhāra and Jājali and the one between Kauśika and the Vyādha. As Proudfoot explains: "In both stories a brāhman whose sin is arrogance is sent to seek instruction from a town-dwelling trader of humble status. The outward similarity is so striking that the two stories have been seen as versions of a common prototype" (1987: 156).

As Proudfoot points out, the similarities between these stories had already been noted by Joseph Dahlmann, Adolf Holtzmann, and Moriz Winternitz. However, Proudfoot rejects the possibility of a common prototype, arguing that "in their original forms" these stories "had nothing in common except the motif of the brāhman's being humbled by learning virtue from a common man" and that other similarities seem "fortuitous" (1987: 244n13). As explained above, this article does not look for origins or influences, but rather is interested in what these embedded narratives teach us about sūkșma dharma when seen as part of the same "story cluster."

In addition to being depicted as arrogant, both Kauśika and Jājali are characterized as lacking in their understanding of dharma. Like Kauśika who is depicted by the Pativratā as not truly understanding dharma, Bhīṣma describes Jājali as not comprehending dharma (12.253.15). Although both stories include the motif of the non-Brāhmaṇa teaching the Brāhmaṇa, it is notable that the non-Brāhmaṇa characters have different caste identities from each other: in Bhīṣma's account Tulādhāra is a Vaiśya, but the Vyādha in Mārkaṇdeya's account is a Ś̄̄dra. The relative difference between the Vaiśya and Ścudra might explain why Kauśika 
emphasizes the caste differences with his interlocutor more than Jājali does. Nevertheless, the boundaries between Vaiśyas and Sūdras can sometimes be blurred in the Mahābhārata. In the Bhagavad Gittā, as Thayanithy reminds us (2018: 189), Kṛ̣na identities Vaiśyas, alongside Ś̄ūras and women, as being low-born (pāpayonaya) (6.31.32).

Interestingly, Proudfoot has argued that Tulādhāra's teaching is specifically representative of the outlook of a tradesman, particularly in how he discusses his ethical approach to "balancing": "Tulādhāra's merchandise consists of spices which must be weighed out, juices which must be measured out. The balances $(t u l \bar{a})$ have connotations of equanimity or indifference" (1987: 106). Indeed, Tulādhāra's name means "bearing a balance." Although I agree that Tulādhāra uses the language of a trader, I remain unconvinced by Proudfoot's further suggestion that "market forces" influence Tulādhāra's outlook: "Tulādhāra speaks as a member of a specialized class whose livelihood turned on monetized, depersonalized exchanges and depended upon the unfathomable operation of market forces....Tulādhāra's world-view is not merely a rationalization of his mode of living; it can also be seen as an outlook rooted directly in the merchant's experience of life" (1987: 108). Although Tulādhāra's class identity emphasizes certain aspects of his teachingjust as the identities of the Pativratā as a housewife and the Vyādha as a butcher highlight certain aspects of their teachings-I would suggest that Tulādhāra's instruction resonates too closely with these other non-Brāhmaṇa teachers to be linked specifically with the merchant class. The important point here is that Tulādhāra offers a teaching that emphasizes his ability to achieve the highest understanding of dharma by means of his everyday practices as a householder. In this light, Tulādhāra's balancing_-his careful weighing up of every situation—does not refer to his unique susceptibility to market forces as a tradesman, but rather more generally to his sustained reflection on his daily responsibilities, a reflexivity that all householders can have towards their everyday practices.

Indeed, in addition to its similarities with the encounter between the Vyādha and Kauśika, the Tulādhāra/Jājali episode has resonances with the Pativratā Upākhyāna as a whole. One such shared feature is the foreknowledge the non-Brāhmaṇa characters have about the Brāhmaṇas. As we have seen, the Pativratā knows that Kauśika has killed the egret, while the Vyādha knows that Kauśika has sought him out because of the Pativratā's instruction. Similarly, when Jājali approaches him, Tulādhāra already knows about the birds that lived in his matted hair and his pride for having achieved feats of austerity. In all three cases, not only do non-Brāhmaṇa characters understand dharma in ways that Brāhmaṇas do not, but their understanding endows them with the power to know things about Brāhmanas that they otherwise would not be able to know.

In conclusion, the Tulādhāra/Jājali episode offers an understanding of dharma's subtlety that resonates with the teachings of the other embedded narratives. According to Tulādhāra, sūkșma dharma is beyond social expectations and social conventions. Tulādhāra demonstrates this understanding through his family duty and his sustained control over his thoughts and emotions. Although Tulādhāra, along with the Pativratā and the Vyādha, characterizes the subtlety of dharma as difficult to fathom, each of these non-Brāhmana teachers is able to articulate their 
understanding to their Brāhmaṇa audience. In this way, their ability to express a subtle understanding of dharma in a communicable teaching shows that they do not perform their duties passively, but with engaged reflection.

\section{Subaltern Understandings of Sūkșma Dharma}

Our starting point for looking at these embedded narratives together was that they are three of only four occasions in the Mahäbhärata where an embedded narrative is used to explain sūksma dharma. We have also noted that these three embedded narratives can be considered as belonging to a story cluster, as they share a number of signifiers, including resonances with the Upaniṣads, an emphasis on ahims $\bar{a}$, and non-Brāhmaṇa teachers.

These three embedded narratives resonate with the Upanișads insofar as they have a tendency to depict the highest knowledge as esoteric and elusive. In our first example, Krṣna describes dharma as unfathomable and as a secret teaching. In the Pativratā Upākhyāna, the Pativratā tells Kauśika that dharma is difficult to know and the Vyādha offers a number of teachings that resonate with the Upanișads, such as an ethical understanding of karma, the immortality of the self, and understanding the self (ātman) as the highest knowledge. Meanwhile, Tulādhāra characterizes a subtle understanding of dharma as secret. If we see dharma's characterization as subtle as an Upanișadic trope, then it is also worth noting other imagery associated with the Upanișads. We saw that the Vyādha uses a chariot metaphor reminiscent of the Katha Upanișad when talking about the self, while Tulādhāra refers to the two paths of the dead, a teaching articulated in the Bṛadāranyaka and Chāndogya Upanișads, and compares the difficulty of knowing dharma to traversing a razor's edge, a metaphor used in the Katha Upanișad.

Another common feature shared by these stories is their emphasis on nonviolence. As we have seen, ahims $\bar{a}$ has a wide range of meanings, from the literal meaning of not killing to the more general implication of compassion for all living beings. In the Karṇa Parvan, Kṛ̣na offers his accounts of Balāka and Kauśika to persuade Arjuna not to carry out an act of violence against his brother, while instructing him that "one should never kill in any way at all" (8.49.20). Meanwhile, the Pativratā offers her counsel to Kauśika in direct response to his violent act of killing the egret, telling him to control his "anger" (krodha) (3.197.31, 3.197.33). Although she does not use the term ahimsā explicitly, she nevertheless indicates her opposition to killing when she instructs Kauśika that a true Brāhmana is one who does not injure (himsa) others when injured himself (3.197.32). Meanwhile, the Vyādha, who uses the term ahimsā on several occasions, advocates a more general compassion for all living beings. The Vyādha's views on violence, however, are more equivocal, because in addition to denouncing injury to any creatures, he also defends meat-eating (3.199.11). Compared to both the Pativratā and Vyādha, Tulādhāra is much more explicit in his emphasis on nonviolence, not only using the term ahims $\bar{a}$ several times $(12.254 .20,12.254 .29,12.255 .24,12.256 .6)$, but also equating ahims $\bar{a}$ with the highest dharma (12.254.29). Like the Vyādha, he also extends his understanding of ahims $\bar{a}$ beyond not killing to nonharm and concern for 
others, associating dharma with "compassion for the welfare of all creatures" (12.254.5), announcing that he lives by "that conduct which is the highest dharma, without harm to creatures, or failing that with a minimum of harm" (12.254.6), and equating knowing dharma with always being a friend of all creatures and always acting for the good of all creatures (12.254.9).

This emphasis on nonviolence and related ideals not only demonstrates the adoption of ascetic values into the ideals of householders, but also offers a scathing criticism of renunciation. In both Kṛṣna's and Mārkaṇdeya's stories in particular, renunciation is shown to lead to violence, however inadvertent it might be. Both Kṛ̣na and Mārkaṇdeya use the character of Kauśika to explore the weaknesses of the renunciate life, showing that the pursuit of one's own spiritual goals can lead to the neglect and injury of others. Indeed, when the Pativratā assures Kauśika that she understands the power of Brāhmanas, she depicts their power as deriving from an anger that reveals their inability to retain control over their emotions. In contrast, the teachings of the Pativratā, as well as those of the Vyādha and Tulādhāra, show that householders are better able to achieve the subtle dharma of nonviolence than renunciates.

Another shared signifier among these stories is the motif of reversing the hierarchy between Brāhmaṇas and non-Brāhmaṇas. Although the characters in Krṣna's stories do not encounter each other directly, his parables, nonetheless, contrast a non-Brāhmaṇa character who exemplifies a higher understanding of dharma, with a Brāhmaña character whose lack of understanding leads to the harm of others. This theme of contrasting the non-Brāhmaṇa and Brāhmaṇa characters is expanded significantly in the Pativratā Upākyhāna as Kauśika receives teachings on dharma's subtlety from characters of a different gender and a different caste status. Meanwhile, in Bhīṣma's story the trader Tulādhāra offers a teaching on sūkṣma dharma to the Brāhmaṇa Jājali.

My aim in addressing these stories as a story cluster, however, is not merely to identify shared signifiers among them, but, more significantly, to argue that when read together these embedded narratives offer a coherent and consistent understanding of dharma's subtlety. One aspect of this understanding is that sükșma dharma involves recognizing the exceptions to rules and acting in ways that may violate normal or traditional expectations. As we have seen, some characters explicitly state that rules can be broken. Kṛṇa tells Arjuna that lies are truth and truth lies, Yudhisthira sees adharma as appearing in the guise of dharma, and the Vyādha tells Jājali that dharma is not the way of the world. Moreover, the marginal status of the characters in these stories contributes towards portraying sūkșma dharma as a reversal of norms.

As we have seen, however, the implications of the marginal status of the Pativratā, the Vyādha, and Tulādhāra is a complex issue. Although I have argued that these characters portray sūkșma dharma as an understanding of dharma that is universally accessible, regardless of gender or caste, both Dhand and Thayanithy have interpreted these characters as literary devices for Brāhmaṇa authors to communicate a reactionary ideology. As such, Thayanithy sees the teachings of these characters as voices "added to the text, validating the discourse on varna with the very absence of the subaltern's own voice" (2018: 191). Despite recognizing a 
"subversive" side to their teachings, Dhand finds the examples of the Pativratā and the Vyādha "unsettling," as she sees them as conveying "attitudes of acquiescence to one's lot in life" (2018: 102, 103). Although I acknowledge that these stories can be read in terms of marginal characters making a virtue of their own exploitation, I have argued that our readings should not be limited to that interpretation.

As we have seen, that interpretation relies too much on the assumption that these stories are representative of a thoroughgoing Brāhmanical ideology that, according to Thayanithy, attempts to exert "absolute control" over women and Śūdras (2018: 206). Although this might describe the agenda of some of those involved in the complex process of contributing towards composing the text, my own starting point in interpreting the Mahäbhärata is as a text that includes a variety of voices and represents a diversity of views. As such, while I agree that these stories might reinforce strict Brāhmanical values in some ways, I think there is also evidence to support understanding these stories as challenging some of the very hierarchies they seem to reinforce.

Another reason I have reservations about Dhand's and Thayanithy's interpretations of these stories is because I think they offer a rather limited way of understanding agency. With the work of Mahmood in mind, I have argued that the Pativratā, the Vyādha, and Tulādhāra use values associated with passivity and submissiveness as idioms through which to assert their presence in the sphere of deliberations about dharma - a sphere that might otherwise restrict people of their social status. Read in this way, rather than as examples of submission, we can see them as examples of empowerment within otherwise strictly bounded roles.

Moreover, the Pativratā, the Vyādha, and Tulādhāra do more than merely enact their dharmic obligations, as each one of them challenges traditional caste and/or gender hierarchies when they reject the authority of their Brāhmaṇa interlocutor. By demonstrating their superior understanding of dharma, they expose the limitations of the knowledge of Brāhmaṇas and thus a cornerstone of Brāhmaṇical authority. So, while it is true that these stories reinforce social hierarchies to some degree, their conservative elements are challenged by their depiction of knowledge as based on conduct rather than birth and their overriding message that anyone, regardless of gender or caste, can know the highest teachings of dharma.

Beyond being articulated by characters of relatively low social status, the teachings of the Pativratā, the Vyādha, and Tulādhāra convey a shared understanding of the subtlety of dharma in terms of an ethics of engagement in everyday life. As we have seen, each of them emphasizes ascetic ideals of self-control and selfmastery. By drawing on their mundane responsibilities as a housewife, a butcher, and a trader, the characters within these stories present an understanding of sükșma dharma as an ongoing process that is cultivated through habitual behavior. We see this in particular in the words of Krṣna, Kauśika, and Tulādhāra, all of whom describe dharma as a subtle way or a path. We have also seen that the Pativratā, the Vyādha, and Tulādhāra all describe dharma as "constant" (śáśvata), implying that an understanding of its subtleties is developed through continuous practice. That the Pativratā, the Vyādha, and Tulādhāra all ground their knowledge in their everyday duties indicates that an understanding of sūkșma dharma entails the assiduous performance of responsibilities towards others. 
Moreover, another commonality among the teachings of these subtales is that dharma's subtlety is revealed through acts of spontaneity. This is reflected in the cases where a character's understanding of dharma is tested by their split-second actions and decisions. Indeed, each of our embedded narratives hinges on an impromptu decision made in response to an unexpected situation: Should Balāka kill the beast? Should Kauśika lie? Should Kauśika be angry when a bird defecates on his head? Should the Pativratā attend to a Brāhmaṇa guest when her husband comes home? Should Jājali be boastful about his ascetic accomplishments? In all of these cases, an instantaneous decision appears to be the measure of whether or not a person has developed an understanding of sūkșma dharma. In each story, a person's character is demonstrated by what we might see as their intuitive choices. If this is the case, then an understanding of dharma's subtlety is not only manifested through discipline, but also involves cultivating an instinct for when to deviate from dharmic norms. It is not about slavishly following rules or uncritically performing duties, but rather about developing a sense for when the normal rules no longer apply. According to this depiction, sūkșma dharma is not a knowledge that can be calculated or discerned, but rather a disposition that is cultivated through continuous practice. In other words, the teachings of the subtle nature of dharma imply that if one reflexively performs one's obligations to others, one can develop a capacity to determine how to act in moments of moral ambiguity.

As these narratives on subtle dharma emphasize, there are no rules that will work in all circumstances. In this context, it is instructive to compare these depictions of dharma as sūkșma with apad-dharma, which is a type of dharma that inverts normal codes of behavior. As Bowles defines it, appad-dharma "fundamentally means 'right conduct in times of distress,' and refers to the relaxing of normative rules of behavior when extraordinary social, environmental or other difficulties, have made these normative rules difficult to follow. In short, apad-dharma refers to exceptional rules for exceptional circumstances" (2007: 2).

If apad-dharma refers to breaking the normal rules of dharma in extreme circumstances, we might see an understanding of sūkșma dharma as giving license to break the normal rules in everyday situations. Within the Mahābhārata, āpaddharma is put into effect in situations such as a flood or a famine. In comparison, the narratives we have examined about the subtle nature of dharma take place in more mundane circumstances. Moreover, the characters who invoke apad-dharma tend to be Brāhmaṇas and kings, while, as we have seen, understandings of sūkșma dharma are enacted by characters of more subaltern status. Finally, whereas apad-dharma has its own set of rules that can be anticipated in advance in situations that would be widely recognized as extreme, a subtle understanding of dharma is enacted spontaneously and intuitively. In this way, part of what makes sūkșma dharma so difficult to understand is that the circumstances for its invocation are not immediately obvious. With sūksma dharma there is always unpredictability and uncertainty about determining when to abide by the normal rules and when to violate them.

Despite its unpredictability and uncertainty, not to mention the Upanișadic rhetoric of elusiveness that some teachers use to describe it, dharma's subtlety is not completely beyond explanation. As Matilal puts it: "it is very difficult but not 
impossible to understand the extremely subtle ways of dharma" (2002: 28). Indeed, as we have seen throughout these stories, the Mahābhārata presents sūkșma dharma as an understanding that can be shared and communicated, as the Pativratā, the Vyādha, and Tulādhāra are all able to do. The way it is communicated, however, defies convention. Although Krṣna says that dharma's subtle way can be learned through scripture, the Pativratā, the Vyādha, and Tulādhāra portray subtle dharma as an understanding that is learned through reflecting upon one's own actions. This, of course, is why sükșma dharma is more available to women and men of lower classes than knowledge based on scripture and lineage. Although the Pativratā mentions the Vedas, and the Vyādha and Tulādhāra employ Upanișadic imageryperhaps suggesting a familiarity with scripture - their own understanding of the subtle nature of dharma has been derived from their reflective daily performance of their responsibilities to others, not from texts or teachers.

\section{Conclusion}

As we have seen throughout this article, some of the most prominent teachers of sūkșma dharma in the Mahābhārata are non-Brāhmanas who appear in the text's embedded narratives. We might wonder, then, how representative their views are of the Mahābhärata's central teachings. At first glance, it might seem that the voices of subaltern characters are reduced to the margins of the text, tucked away from view within embedded stories. However, if the teachings of the Pativratā, the Vyādha, and Tulādhāra might seem muted within substories, their voices are amplified when their words are repeated by some of the Mahäbhärata's most authoritative teachers. As we have seen, Kṛ̣ṇa, Mārkaṇdeya, and Bhīṣma all use stories of subaltern characters to demonstrate their own understandings of sūkșma dharma. Additionally, two of the other characters in the central narrative who invoke sūkșma dharma are Yudhișthira and Draupadī, both of whom are present during the embedded narratives told by Mārkaṇ̣eya and Bhīṣma, while Yudhișthira is also present when Kṛ̣nạa tells Arjuna the stories of Balāka and Kauśika. Although both Yudhișțira and Draupadī hear these stories after they speak about dharma's subtlety themselves, given the small number of stories associated with sūkșma dharma in the Mahābhärata, we might reasonably assume that stories like them, if not versions of some of these same stories, could have informed their own understandings.

Presumably, it is because of the words of Yudhișthira, Bhīṣma, and Draupadī in some of the text's most central episodes that Ramanujan and others have identified sükșma dharma as one of the central teachings of the Mahābhärata. Beyond its general portrayal as ambiguous and complex, however, if we want to understand more specific meanings and implications of süssma dharma, then we have to look to the embedded narratives that explain and demonstrate this otherwise elusive teaching. By doing so, we can appreciate the subtle connection between some of the most authoritative voices in the central narrative and the teachings of a housewife, a hunter, and a trader. 
Acknowledgments I would like to thank the following people who read drafts of this article and thought along with me about sükșma dharma: Naomi Appleton, Christopher Austin, Jonathan Geen, Jacqueline Suthren Hirst, Kumkum Roy, and Lynn Thomas. I would also like to thank the anonymous reviewers for their constructive feedback.

Open Access This article is licensed under a Creative Commons Attribution 4.0 International License, which permits use, sharing, adaptation, distribution and reproduction in any medium or format, as long as you give appropriate credit to the original author(s) and the source, provide a link to the Creative Commons licence, and indicate if changes were made. The images or other third party material in this article are included in the article's Creative Commons licence, unless indicated otherwise in a credit line to the material. If material is not included in the article's Creative Commons licence and your intended use is not permitted by statutory regulation or exceeds the permitted use, you will need to obtain permission directly from the copyright holder. To view a copy of this licence, visit http:// creativecommons.org/licenses/by/4.0/.

\section{References}

Adluri, Vishwa. 2016. "Introduction: From Supplementary Narratives to Narrative Supplements." In Vishwa Adluri and Joydeep Bagchee, eds., Argument and Design: The Unity of the Mahābhārata, 19. Leiden: Brill.

Adluri, Vishwa. 2017. "Hindu Studies in a Christian, Secular Academy." International Journal of Dharma Studies 5, 6: 1-31.

Adluri, Vishwa and Joydeep Bagchee, eds. 2016. Argument and Design: The Unity of the Mahābhārata. Leiden: Brill.

Appleton, Naomi and Chris Clark. Forthcoming. "Beyond Textual and Visual 'Versions': The Story Cluster of the Six-Tusked Elephant Bodhisattva." In Naomi Appleton, ed., Narrative Visions and Visual Narratives in Indian Buddhism. Sheffield: Equinox.

Biardeau, Madeleine. 1984. "Nala et Damayantī, héros épiques" (Part I). Indo-Iranian Journal 27, 4: 24774.

Biardeau, Madeleine. 1985. "Nala et Damayantī, héros épiques" (Part II). Indo-Iranian Journal 28, 1: 134.

Black, Brian. 2007a. The Character of the Self in Ancient India: Priests, Kings, and Women in the Early Upanișads. Albany: State University of New York Press.

Black, Brian. 2007b. "Eavesdropping on the Epic: Female Listeners in the Mahābhārata." In Simon Brodbeck and Brian Black, eds., Gender and Narrative in the Mahābhārata, 53-78. London: Routledge.

Black, Brian. 2011. "The Rhetoric of Secrecy in the Upanișads." In Steven E. Lindquist, ed., Religion and Identity in South Asia and Beyond: Essays in Honor of Patrick Olivelle, 101-25. London: Anthem Press.

Black, Brian. 2018. "The Upanișads and the Mahābhārata." In Signe Cohen, ed., The Upaniṣads: A Complete Guide, 186-99. New York: Routledge.

Black, Brian. 2021. In Dialogue with the Mahābhārata. Abingdon: Routledge.

Bowles, Adam. 2007. Dharma, Disorder and the Political in Ancient India: The Apaddharmaparvan of the Mahābhārata. Leiden: Brill.

Bronkhorst, Johannes. 2011. Buddhism in the Shadows of Brahmanism. Leiden: Brill.

Dhand, Arti. 2008. Woman as Fire, Woman as Sage: Sexual Ideology in the Mahābhārata. Albany: State University of New York Press.

Dhand, Arti. 2018. "Karmayoga and the Vexed Moral Agent." In Sibesh Chandra Bhattacharya, Vrinda Dalmiya, and Gangeya Mukherji, eds., Exploring Agency in the Mahābhārata: Ethical and Political Dimensions of Dharma, 81-106. Abingdon: Routledge.

Fitzgerald, James L. 2006. "Negotiating the Shape of 'Scripture': New Perspectives on the Development and Growth of the Mahābhārata Between the Empires." In Patrick Olivelle, ed., Between the Empires: Society in India 300 BCE to 400 CE, 257-86. New York: Oxford University Press. 
Hara, Minoru. 1997. "A Note on dharmasya sūkșmā gatih." In Eli Franco and Karin Preisendanz, eds., Beyond Orientalism: The Work of Wilhelm Halbfass and Its Impact on Indian and Cross-Cultural Studies, 515-32. Amsterdam: Rodopi.

Hegarty, James. 2019. "Models of Royal Piety in the Mahābhārata: The Case of Vidura, Sanatsujāta and Vidurā." In Brian Black and Chakravarthi Ram-Prasad, ed., In Dialogue with Classical Indian Traditions: Encounter, Transformation and Interpretation, 211-27. Abingdon: Routledge.

Hiltebeitel, Alf. 2005. "Not Without Subtales: Telling Laws and Truths in the Sanskrit Epics." Journal of Indian Philosophy 33, 4: 455-511.

Hiltebeitel, Alf. 2011. Dharma: Its Early History in Law, Religion, and Narrative. New York: Oxford University Press.

Hudson, Emily T. 2013. Disorienting Dharma: Ethics and the Aesthetics of Suffering in the Mahäbhärata. New York: Oxford University Press.

Leslie, Julia. 1998. "A Bird Bereaved: The Identity and Significance of Vālmīki’s krauñca." Journal of Indian Philosophy 26, 5: 455-87.

Mahābhārata. 1927-66. The Mahābhārata for the First Time Critically Edited (general eds. Vishnu S. Sukthankar [1927-43], S. K. Belvalkar [1943-61], and P. L. Vaidya [1961-66], with the cooperation of other scholars). 19 volumes. Poona: Bhandarkar Oriental Research Institute.

Mahābhārata. 1975. The Mahābhārata: 2. The Book of the Assembly Hall; 3. The Book of the Forest (trans. and ed. J. A. B. van Buitenen). Chicago: University of Chicago Press.

Mahābhārata. 1990 [1884-96]. The Mahābhārata of Krishna-Dwaipayana Vyasa Translated into English Prose from the Original Sanskrit Text (trans. K. M. Ganguli). 12 volumes. New Delhi: Munshiram Manoharlal.

Mahābhārata. 2008. Mahābhārata. Book Eight: Karna (trans. Adam Bowles). Volume 2. New York: New York University Press / JJC Foundation.

Mahmood, Saba. 2006. "Feminist Theory, Agency, and Liberatory Subject: Some Reflections on the Islamic Revival in Egypt." Temenos 24, 1: 31-71.

Matilal, Bimal Krishna. 1991. "Krṣna: In Defence of a Devious Divinity." In Arvind Sharma, ed., Essays on the Mahābhārata, 401-18. Leiden: Brill.

Matilal, Bimal Krishna. 2002. The Collected Essays of Bimal Krishna Matilal. Volume 2: Ethics and Epics (ed. Jonardon Ganeri). New Delhi: Oxford University Press.

Patton, Laurie L. 2007. "How Do You Conduct Yourself? Gender and the Construction of a Dialogical Self in the Mahābhārata." In Simon Brodbeck and Brian Black, ed., Gender and Narrative in the Mahābhärata, 97-109. Abingdon: Routledge.

Proudfoot, I. 1987. Ahimsā and a Mahābhārata Story: The Development of the Story of Tulädhāra in the Mahābhārata in Connection with Non-Violence, Cow Protection and Sacrifice. Asian Studies Monographs, New Series 9. Canberra: Faculty of Asian Studies, Australian National University.

Ramanujan, A. K. 1991a. "Repetition in the Mahābhärata." In Arvind Sharma, ed., Essays on the Mahābhārata, 419-43. Leiden: Brill.

Ramanujan, A. K. 1991b. "Three Hundred Rämāyanas: Five Examples and Three Thoughts on Translation." In Paula Richman, ed., Many Rāmāyanas: The Diversity of a Narrative Tradition in South Asia, 22-48. Berkeley: University of California Press.

Reich, Tamar Chana. 1998. "A Battleground of a Text: Inner Textual Interpretation in the Sanskrit Mahābhārata." Ph.D. Dissertation, University of Chicago.

Thayanithy, Maithili. 2018. "Can the Subaltern Speak? Revisiting the Expositions of Dharma in the Mahābhārata." In Simon Brodbeck, Adam Bowles, and Alf Hiltebeitel, eds., The Churning of the Epics and Purānas: Proceedings of the Epics and Purānas Section at the 15th World Sanskrit Conference, 189-208. New Delhi: Dev Publishers \& Distributors.

Upanișads. 1998. The Early Upanișads: Annotated Text and Translation (trans. and ed. Patrick Olivelle). New York: Oxford University Press.

\section{Publisher's Note}

Springer Nature remains neutral with regard to jurisdictional claims in published maps and institutional affiliations. 